\title{
Prenatal diagnosis of umbilical artery thrombosis in the second trimester: a case report
}

\author{
Alev Esercan ${ }^{1}$ (D), Emre Ekmekci \\ ${ }^{1}$ Clinic of Obstetrics and Gynecology, Şanluurfa Training and Research Hospital, Şanhurfa, Turkey \\ ${ }^{2}$ Maternal Fetal Medicine Division, Şanluurfa Training and Research Hospital, Şanluurfa, Turkey
}

\begin{abstract}
Objective: Thrombosis of umbilical artery is a rare condition. The diagnosis is established commonly in the third trimester after detection of fetal distress or intrauterine growth retardation, or could be established after delivery. Also, the management of the condition is conflicting after the diagnosis.

Case: Here we reported an umbilical artery thrombosis case that was diagnosed in the second trimester after referral for an umbilical cord cyst. After the diagnosis at 24th week of pregnancy, she had been followed up weekly. She had been delivered electively at the 34th week of pregnancy uneventfully. The diagnosis was confirmed postnatally.

Conclusion: The prenatal diagnosis of umbilical arterial thrombosis is so important to prevent perinatal morbidity. When umbilical cord cysts are detected, further evaluation is required in terms of umbilical artery thrombosis.
\end{abstract}

Keywords: Thrombosis, umbilical artery, umbilical cord.

\section{Introduction}

Thrombosis of umbilical cord vessels is a rare complication during pregnancy and the incidence is reported as 1 in 1300 deliveries by Heifetz. Thrombosis of umbilical vein is more frequent than the arterial thrombosis. ${ }^{[1]}$ Umbilical arterial thrombosis is associated with poor fetal outcomes including intrauterine growth restriction (IUGR) and increased fetal demise. Diagnosis is so difficult and challenging, also the management is so controversial that there is no approved timing of delivery after the diagnosis. Here, we report-
Özet: İkinci trimesterde umbilikal arter trombozunun prenatal tanısı: Olgu sunumu

Amaç: Umbilikal arter trombozu nadir bir rahatsızlıktır. Tanısı genellikle üçüncü trimesterde fetal distres veya intrauterin gelişme geriliğinin tespitinden sonra konulur veya doğumdan sonra tanı koyulabilir. Ayrıca, rahatsızlığın yönetimi de tanı sonrasında çelişkilidir.

Olgu: Çalışmamızda, umbilikal kord kisti için başvuru sonrasında ikinci trimesterde tanısı konulan bir umbilikal arter tromboz olgusunu sunduk. Gebeliğin 24. haftasındaki tanı sonrasında olgu haftalık olarak takip edildi. Olgu, 34. gebelik haftasında sorunsuz şekilde elektif olarak doğum yaptı. Tanı postnatal olarak doğrulandi.

Sonuç: Umbilikal arter trombozunun prenatal tanısı, perinatal morbiditeyi önlemede çok önemlidir. Umbilikal kord kistleri tespit edildiğinde, umbilikal arter trombozu bakımından ek değerlendirme yapılmalıdır.

Anahtar sözcükler: Tromboz, umbilikal arter, umbilikal kord.

ed an umbilical arterial thrombosis that is diagnosed at the 24 weeks of gestation that is followed up to 34 weeks of pregnancy. We obtained the written informed consent from the patient for publication of this case report and any accompanying images.

\section{Case Report}

A 28-year-old gravida 5 para 1 abortion 3, 24 weeks pregnant patient was referred to our maternal-fetal medicine unit due to a cystic structure at the free loop

Correspondence: Emre Ekmekci, MD. Maternal Fetal Medicine Division, Şanlıurfa Training and Research Hospital, Şanlıurfa, Turkey. e-mail: dr.ekmekci@hotmail.com / Received: October 30, 2020; Accepted: February 1, 2021

How to cite this article: Esercan A, Ekmekci E. Prenatal diagnosis of umbilical artery thrombosis in the second trimester: a case report. Perinatal Journal 2021;29(1):79-82. doi:10.2399/prn.21.0291012 


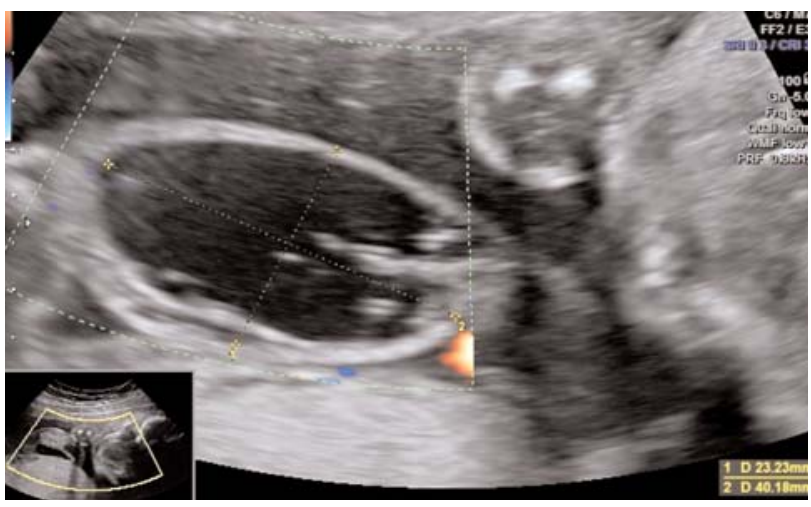

Fig. 1. The periumbilical cord cystic structure.

of umbilical cord. Fetal anatomic survey was completely normal at 21 st week of pregnancy including two umbilical arteries. Patient had an unremarkable past medical history. Only she was using enoxaparin sodium is $4000 \mathrm{IU}(40 \mathrm{mg})$ once daily that was started in the early first trimester by another physician due to previous abortions in the first trimester. But the indication of the enoxaparin use was not clear. Acquired and inherited thrombophilia tests were normal. Our transabdominal ultrasonographic examination revealed a $23 \times 40 \mathrm{~mm}$ thin walled cystic structure surrounding around a part of free umbilical cord loop (Fig. 1). Content of cystic structure was semiechogenic. At longitudinal section of umbilical cord visualized by sonography, a $25 \times 8 \mathrm{~mm}$ sized echogenic structure next to the cystic area is visualized (Fig. 2).

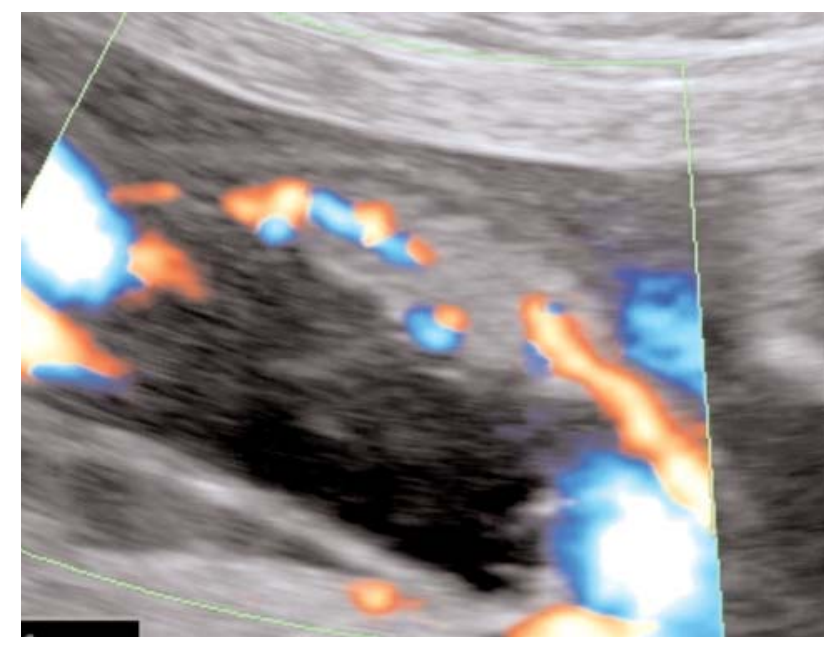

Fig. 3. Minimal blood flow on power Doppler sonography.



Fig. 2. Sonographic view of thrombus.

Doppler flow confirmed two blood flows on cord, one artery and one vein. The other umbilical artery vessel blood flow was clogged by the thrombus. Minimal passage through the thrombus could be visualized by power Doppler (Fig. 3). Only one paravesical umbilical arterial blood flow was present. Fetal biometric measurements were coherent with gestational age. Umbilical artery pulse Doppler values were normal. Anatomic survey did not reveal any extra abnormality. Fetal echocardiography and cardiac rhythm was normal. Patient is informed about abnormality and called for weekly follow-up. The enoxaparin is not stopped and continued. The cystic structure surrounding the cord in first sonography disappeared one week later. On weekly follow-ups, the thrombus is evaluated and the cord vessels were examined about a new thrombus. The cranial structures of the fetus is examined about a probable emboli. After the 28th week of pregnancy fetal well-being was also evaluated by weekly nonstress test. Timing of delivery was planned at 34th week. After the 31 st week of pregnancy, a mild fetal intrauterine growth retardation was started but Doppler velocimetry was normal and patient was followed up to 34 weeks. A healthy female infant weighing 2250 grams was delivered electively by cesarean section, with Apgar scores of 6 at 1 minute and 8 at 5 minutes on the 34 week of pregnancy. Baby did not have any signs associated with thrombosis. The thrombus in the umbilical artery is confirmed macroscopically after delivery (Figs. 4 and 5). Also, the diagnosis is confirmed histopathologically. The baby is followed in neonatal intensive care unit for 5 days and then discharged from hospital. 


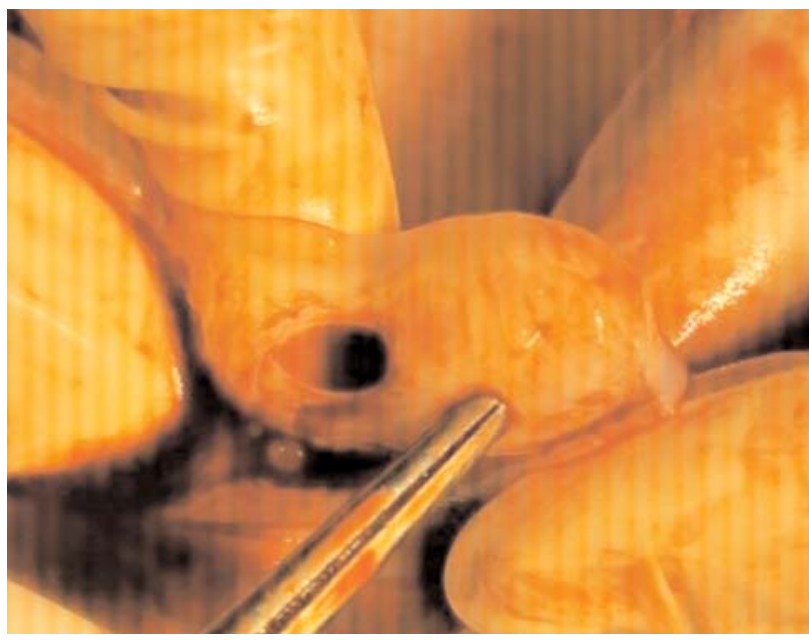

Fig. 4. Thrombus in the umbilical artery and the intact artery and vein.

\section{Discussion}

The prognosis of umbilical arterial thrombosis is worse than umbilical venous thrombosis and arterial thrombosis is associated with increased perinatal morbidity, IUGR and increased fetal mortality. Thrombosis of umbilical artery is rare and no clear data exists regarding the management of this condition. ${ }^{[2]}$ The reason of umbilical vessels thrombosis is unclear. It is asserted that umbilical cord abnormalities cause thrombosis. These may be primarily the abnormal structure of the umbilical cord, like hypercoiling or elongation or mechanical factors that applies pressure on the vessels like cystic structures, placental tumors. ${ }^{[3]}$ Umbilical vessel thrombosis may also be associated with abnormal fetal coagulation, maternal diabetes mellitus, infection, and smoking. ${ }^{[4]}$ Matsumoto et al. ${ }^{[5]}$ reported an umbilical arterial thrombosis that was associated with an extra-abdominal umbilical vein varix. $\mathrm{Li}$ et al. ${ }^{[6]}$ reported an umbilical arterial thrombosis that was associated with hypercoiling of umbilical cord. These abnormalities may induce flow stasis and thrombosis of the umbilical artery. In our case the diagnosis was made after the detection of umbilical cord cystic structure. However, we are not sure that it was a real cystic structure or an extravasation subsequent to the thrombosis. Because the cystic structure disappeared one week later.

Papers about prenatal detection of umbilical arterial thrombosis are limited and most of them have been

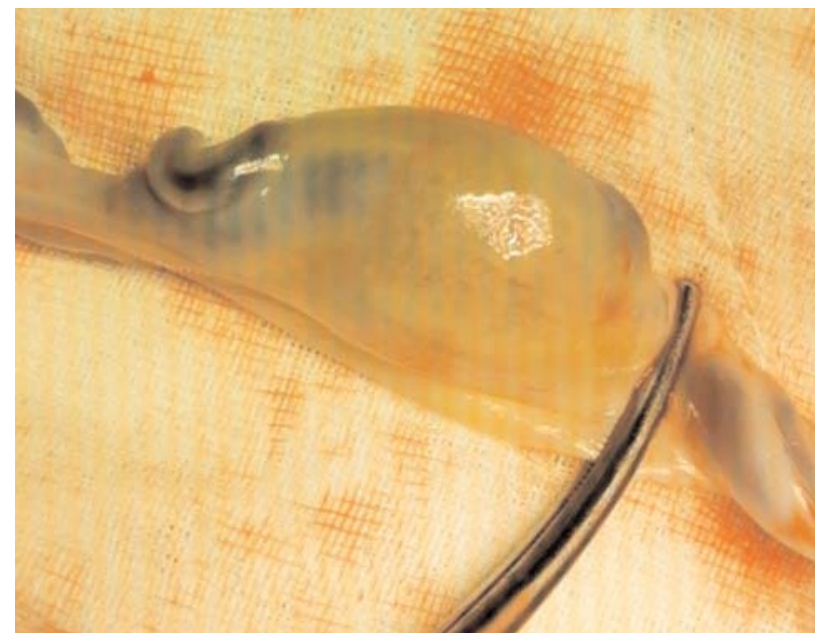

Fig. 5. Macroscopically view of thrombosis part of umbilical cord.

diagnosed postnatal when the baby has been delivered due to acute fetal distress. Klaritsch et al. ${ }^{[7]}$ described 'grabbed orange sign' for the sonographic detection of umbilical artery thrombosis. In our case, we directly detected the large echogenic thrombus in the vessel but the cystic structure have attracted attention us on the cord loop to look more carefully. A cystic umbilical cord structure may be critical sign to alert the physician about the thrombosis.

The thrombosis of vessels does not always completely block the circulation. Completely block of umbilical vein is lethal for the fetus; however, that is not same for the artery. ${ }^{[8]}$ In our case the artery was completely blocked, and only minimal flow could be visualized by power Doppler at very low pulse repetition frequencies. Acute thrombosis may result with sudden stillbirth, acute fetal distress or IUGR. ${ }^{[9]}$ Sato and Benirschke also reported results of 11 cases with umbilical arterial thrombosis and reported two with stillbirths and three with severe intrauterine growth restriction. ${ }^{[10]}$ We had only a mild IUGR at fetus and was started around 31 weeks of pregnancy that was about two months later after the diagnosis.

In the literature, because most cases were diagnosed with acute fetal distress and babies were delivered emergently, there is only a few cases whose pregnancies were followed after prenatal diagnosis. We could only find reports on two separate cases diagnosed at 32 and 33 weeks of gestation and delivered electively at 34 
weeks of gestation. ${ }^{[2,11]}$ We electively delivered the baby by cesarean section at 34 weeks of gestation. Our case is characterized with longest follow-up time after the diagnosis in the literature.

\section{Conclusion}

In conclusion, prenatal detection of umbilical arterial thrombosis is so crucial to prevent perinatal morbidity and mortality. Despite this, it is not always possible to prevent adverse outcomes despite early diagnosis. This should be noted. More careful sonographic evaluation of the umbilical cord will be useful for the early diagnosis of thrombosis and to detect high-risk patients for umbilical vessel thrombosis.

Funding: This work did not receive any specific grant from funding agencies in the public, commercial, or not-for-profit sectors.

Compliance with Ethical Standards: The authors stated that the standards regarding research and publication ethics, the Personal Data Protection Law and the copyright regulations applicable to intellectual and artistic works are complied with and there is no conflict of interest.

\section{References}

1. Heifetz SA. Thrombosis of the umbilical cord: analysis of 52 cases and literature review. Pediatr Pathol 1988;8:37-54. [PubMed] [CrossRef]

2. Lutfallah F, Oufkir N, Markou GA, Frimigacci D, Poncelet C. A case of umbilical artery thrombosis in the third trimester of pregnancy. Am J Case Rep2018;19:72-5. [PubMed] [CrossRef]
3. Tanaka K, Tanigaki S, Matsushima M, Miyazaki N, Hashimoto $\mathrm{R}$, Izawa T, et al. Prenatal diagnosis of umbilical artery thrombosis. Fetal Diagn Ther 2014;35:148-50. [PubMed] [CrossRef]

4. Avagliano L, Marconi AM, Candiani M, Barbera A, Bulfamante G. Thrombosis of the umbilical vessels revisited. An observational study of 317 consecutive autopsies at a single institution. Hum Pathol 2010;41:971-9. [PubMed] [CrossRef]

5. Matsumoto Y, Yanai A, Kamei S, Yamaguchi A, Nakamine H, Fujita K. A case report of umbilical vein varix with thrombosis: prenatal ultrasonographic diagnosis and management. Case Rep Obstet Gynecol 2019;2019:7154560. [PubMed] [CrossRef]

6. Li H, Wu Q, Wei W, Lin X, Zhang X. Umbilical artery thrombosis: two case reports. Medicine (Baltimore) 2019;98: e18170. [PubMed] [CrossRef]

7. Klaritsch P, Haeusler M, Karpf E, Schlembach D, Lang U. Spontaneous intrauterine umbilical artery thrombosis leading to severe fetal growth restriction. Placenta 2008;29:3747. [PubMed] [CrossRef]

8. Dussaux C, Picone O, Chambon G, Tassin M, Martinovic J, Benachi A, et al. Umbilical vein thrombosis: to deliver or not to deliver at the time of diagnosis? Clin Case Rep 2014;2:2713. [PubMed] [CrossRef]

9. Alhousseini A, Jaiman S, Hernandez-Andrade E, Zeineddine S, Qureshi F, Jacques SM. Umbilical artery thrombosis with associated acute and severe fetal growth restriction and transient severe protein $S$ deficiency: report of a case with prenatal ultrasound diagnosis allowing for timely intervention and good outcome. Case Rep Obstet Gynecol 2018;2018:6324362. [PubMed] [CrossRef]

10. Sato Y, Benirschke K. Umbilical arterial thrombosis with vascular wall necrosis: clinicopathologic findings of 11 cases. Placenta 2006;27:715-8. [PubMed] [CrossRef]

11. de Oliveira GH, de Morales Dias C, Vaz-Oliani DCM, Oliani AH. Intrauterine thrombosis of umbilical artery - case report. Sao Paulo Med J 2016;134:355-8. [PubMed] [CrossRef] 94042 , USA.

Publisher's Note: The content of this publication does not necessarily reflect the views or policies of the publisher, nor does any mention of trade names, commercial products, or organizations imply endorsement by the publisher. Scientific and legal responsibilities of published manuscript belong to their author(s). The publisher remains neutral with regard to jurisdictional claims in published maps and institutional affiliations. 